\title{
Raf-1 Kinase Regulates Smooth Muscle Contraction in the Rat Mesenteric Arteries
}

\author{
Kunju Sathishkumar Uma Yallampalli Rebekah Elkins Chandra Yallampalli \\ Department of Obstetrics and Gynecology, University of Texas Medical Branch, Galveston, Tex., USA
}

\section{Key Words}

Blood pressure $\cdot$ Raf-1 $\cdot$ Mitogen-activated protein kinase $\cdot$

Extracellular signal-regulated kinase $\cdot$ Vascular smooth

muscle $\cdot$ Contraction $\cdot$ Protein kinase $C \cdot$ Agonists .

Intracellular calcium hibited by GW5074. However, GW5074 did not have any significant effect on PE/PDBu-induced MEK/ERK activation. The results indicate that Raf-1 kinase plays an important role in the regulation of vascular contractility through regulation of calcium sensitization.

Copyright $\odot 2010$ S. Karger AG, Basel

\begin{abstract}
We investigated the potential role of Raf-1 kinase in mesenteric arterial contraction. Inhibitors of Raf-1 kinase, GW5074, L779450 and ZM 336372 reversed phenylephrine (PE)-induced mesenteric vascular contraction. Studies in vivo in rats showed that GW5074 inhibited PE-induced increase in mean arterial pressure in adult female Sprague-Dawley rats. Isometric tension studies in mesenteric arteries of rats showed that GW5074 did not change the $\mathrm{KCl}$-evoked contraction but significantly inhibited the contractions to $P E, 5$ HT, U46619, endothelin 1, angiotensin II and phorbol 12, 13dibutyrate (PDBu). In mesenteric vascular smooth muscle cells (VSMCs), PE stimulated increase in Raf-1 phosphorylation which was inhibited by GW5074. Measurement of $\left[\mathrm{Ca}^{2+}\right]_{i}$ with Fura-2 showed that GW5074-mediated inhibition of PEinduced contraction was not associated with decreases in $\left[\mathrm{Ca}^{2+}\right]_{\mathrm{i}}$. VSMCs treated with PE exhibited higher levels of the contractile proteins, $\mathrm{p}$-MYPT1 and $\mathrm{p}-\mathrm{MLC}_{20}$, which was inhibited by GW5074. Similarly, PDBu induced increases in phosphorylation of Raf-1, MLC 20 and MYPT1 and this was in-
\end{abstract}

\section{Introduction}

$G$ protein-coupled receptors play a key role in regulation of smooth muscle tone. Activation of $\mathrm{G}$ protein-coupled receptors results in activation of phospholipase $\mathrm{C}$, which then hydrolyses phosphatidylinositol-4,5-bisphosphate $\left(\mathrm{PIP}_{2}\right)$ to generate inositol-1,4,5-trisphosphate $\left(\mathrm{IP}_{3}\right)$ and diacylglycerol. $\mathrm{IP}_{3}$ induces $\mathrm{Ca}^{2+}$ mobilization from intracellular stores, while diacylglycerol activates protein kinase $\mathrm{C}(\mathrm{PKC})[1,2]$. These pathways are considered to be important for vascular contraction, cell growth and proliferation. However, recent studies suggest that the activation of $G$ protein-coupled receptors may have more complicated pathways for vascular contraction than these well-known signal transduction pathways. For example, it has been suggested that mitogen-activated protein (MAP) kinases may be linked to agonist-induced smooth muscle contraction [3-5]. This MAP kinase pathway consists of Raf-1 kinase which phosphorylates and

\section{KARGER}

Fax +41613061234 E-Mail karger@karger.ch www.karger.com
(C) 2010 S. Karger AG, Basel

$1018-1172 / 10 / 0475-0384 \$ 26.00 / 0$

Accessible online at:

www.karger.com/jvr
Dr. Chandra Yallampalli

Department of Obstetrics and Gynecology, University of Texas Medical Branch

301 University Blvd., MRB, 11.138, Rt. 1062

Galveston, TX 77555-1062 (USA)

Tel. +1 409772 7592, Fax +1 409747 0475, E-Mail chyallam@utmb.edu 
activates mitogen-activated protein kinase (MEK), which in turn activates extracellular signal-regulated kinase (ERK). There is convincing evidence to explain that the downstream effectors, MEK/ERK, regulate vascular contraction [6-8]. However, modulation of smooth muscle contraction by MEK/ERK has been shown to be directly regulated by PKC rather than its classical activator, Raf- 1 $[7,9,10]$. To date, there are no studies available to demonstrate the role of the upstream kinase Raf-1 in vascular contraction.

Raf- 1 is a serine/threonine protein kinase that plays an important role in cell survival, proliferation and migration [11]. Raf-1 kinase is shown to be activated in nonproliferative differentiated cells like cardiomycytes $[12,13]$, neurons $[14,15]$ and skeletal muscle cells $[16,17]$. Stimulation of Raf-1 kinase in response to both mechanical load and pharmacological stimulation has been reported in vascular smooth muscle cells [18-21]. Although MEK is the most recognized physiological substrate for Raf-1, growing evidence suggests a link between Raf- 1 and a variety of other downstream effectors [11, 22, 23]. Raf-1 has been shown to play a role in cytoskeletal architecture via its direct association with vimentin kinases [24] and myosin phosphatase [25, 26]. Hirano et al. [27] proposed that Raf-1 kinase may be one of the many kinases that can phosphorylate and inhibit myosin phosphatase. Myosin phosphatase is composed of three subunits: a $37-\mathrm{kDa}$ catalytic subunit (PP1c), a small noncatalytic subunit of unknown function and a 110- to $130-\mathrm{kDa}$ myosin-binding subunit (MYPT1) $[28,29]$. MYPT1 along with PP1c interacts with phosphorylated $20-\mathrm{kDa}$ myosin light chain $\left(\mathrm{MLC}_{20}\right)$ resulting in its dephosphorylation. $\mathrm{MLC}_{20}$ phosphorylation is essential for smooth muscle contraction. The inhibition of myosin phosphatase leading to increased $\mathrm{MLC}_{20}$ phosphorylation has been shown to be a major contributor to $G$ protein-coupled receptor-mediated excitation contraction coupling of smooth muscles [30]. However, the direct role of Raf-1 kinase in vascular contraction is not known.

The present study was aimed to clarify the roles of Raf1 in the excitation-contraction coupling of intact rat mesenteric arterial smooth muscle. We first examined the involvement of Raf-1 kinase in the vascular contraction using three selective inhibitors of Raf- 1 activation, GW5074 (5-iodo-3-[(3,5-dibromo-4-hydroxyphenyl) methylene]-2-indolinone), L779450 (2-(phenyl)-4-(3-hydroxy-4-chlorophenyl)-5-(4-pyridyl)-1H-imidazole) and ZM 336372 (N-[5-(3-dimethylaminobenzamido)-2methylphenyl]-4-hydroxybenzamide). Further in vivo and in vitro studies were done with GW5074 to charac- terize the role of Raf- 1 activation in increased vascular contraction induced by various agonists. This was followed by investigating the roles of Raf-1 in agonistinduced $\mathrm{Ca}^{2+}$ responses, and $\mathrm{MLC}_{20}$ and MYPT1 phosphorylation. To our knowledge, this is the first demonstration of vasodilation by pharmacological inhibition of Raf-1. Raf-1 kinase-mediated phosphorylation of MYPT1 associated with increased $\mathrm{MLC}_{20}$ phosphorylation might play a role in agonist-induced vascular contraction.

\section{Methods}

\section{Animals}

All procedures were approved by the Animal Care and Use Committee at the University of Texas Medical Branch and were in accordance with those published by the US National Institutes of Health Guide for the Care and Use of Laboratory Animals (NIH publication No. 85-23, revised 1996). Adult virgin female Sprague-Dawley rats were obtained from Harlan (Houston, Tex., USA). The animals were housed in a room with a controlled temperature and a 12:12-hour light-dark cycle and were provided food and water ad libitum.

\section{Mean Arterial Pressure}

Sprague-Dawley rats weighing 175-225 g were instrumented for hemodynamic monitoring. Under general anesthesia (ketamine: $45 \mathrm{mg} / \mathrm{kg}$ body weight, and xylazine: $5 \mathrm{mg} / \mathrm{kg}$ body weight; Burns Veterinary Supply, Westbury, N.Y., USA), a right paramedial skin incision was made in the cervical region and the vascular structures were identified. One polyethylene catheter (PE-50; Becton Dickinson, Sparks, Md., USA) was inserted into the external jugular vein and the second was advanced into the common carotid artery. The catheters were tunneled subcutaneously and exteriorized through a skin incision in the interscapular region. After complete recovery from anesthesia, the carotid cannula was connected to a pressure transducer (Kent Scientific, Litchfield, Conn., USA) to record the changes in mean arterial pressure (MAP) and the jugular cannula was used to administer drugs. After ensuring that the MAP was maintained at a stable level, the responses to infusions of phenylephrine (PE; $10-300 \mu \mathrm{g} / \mathrm{kg} / \mathrm{min}$ ) were determined. Each dose of PE was infused for a 3-min period and the MAP was determined as the mean value recorded within the last minute of infusion. The role of Raf- 1 on elevated blood pressure induced by $\mathrm{PE}$ was tested by administration of a bolus dose of GW5074 $(250 \mu \mathrm{g} / \mathrm{kg})$ through the jugular catheter $15 \mathrm{~min}$ prior to challenging with $\mathrm{PE}$.

Tissue Preparation and Force Measurements

Adult female rats were sacrificed by $\mathrm{CO}_{2}$ asphyxiation by slow infusion of the gas into an airtight glass chamber. The mesenteric arcade was quickly removed and immersed in an ice-cold and oxygenated $\left(95 \% \mathrm{O}_{2}\right.$ and $\left.5 \% \mathrm{CO}_{2}\right)$ Krebs physiological saline solution composed of (in $\mathrm{mM}$ ): $\mathrm{NaCl}, 119 ; \mathrm{KCl}, 4.7 ; \mathrm{CaCl}_{2}, 2.5$; $\mathrm{MgSO}_{4}, 1.17 ; \mathrm{NaHCO}_{3}, 25 ; \mathrm{KH}_{2} \mathrm{PO}_{4}, 1.18$; EDTA, 0.026; D-glucose, 5.5 ( $\mathrm{pH}$ 7.4). The arteries were cleaned of all adherent connective tissue, and segments of second-order mesenteric artery (approx. $200 \mu \mathrm{m}$ external diameter) were cut into small rings 
( $2 \mathrm{~mm}$ length) and mounted on a wire myograph (Danish Myograph Technology, Aarhus, Denmark) for recording of isometric tension using Labchart software (ADInstruments, Colorado Springs, Colo., USA). Each vessel ring was placed under optimal stretch, equivalent to an in vivo arterial blood pressure of approximately $100 \mathrm{~mm} \mathrm{Hg}$ using normalization software (ADInstruments). Arterial rings were equilibrated for at least $1 \mathrm{~h}$ before being challenged with pharmacological agents. All studies were done in endothelium-intact rings except for angiotensin II to avoid the endothelial $\mathrm{AT}_{2}$ receptor-mediated opposing effects. The integrity of the endothelium was confirmed by the relaxant response of precontracted rings to acetylcholine $(10 \mu \mathrm{M})$. Concentration-response curves were obtained by cumulative addition of the agonist in approximate one-half $\log$ increments. $\mathrm{EC}_{50}$ values for the agonist in each experiment were taken as the molar concentration at which the contraction-response curve intersected $50 \%$ of the maximum response and were expressed as $\mathrm{pD}_{2}(-\log$ $\mathrm{EC}_{50}$ ) values. All responses are presented as percent of maximal contraction of respective agonists.

Culture of Primary Mesenteric Artery Smooth Muscle Cells

Vascular smooth muscle cells (VSMCs) from mesenteric arteries were isolated under sterile conditions as previously described [31]. In brief, the mesenteric arteries were dissected out and placed in ice-cold Hanks' balanced salt solution (HBSS, containing $0.2 \mathrm{mM} \mathrm{Ca}^{2+}$ and no $\mathrm{Mg}^{2+}$; Cellgro, Herndon, Va., USA), and were carefully cut into small segments and placed in HBSS containing $0.2 \mathrm{mM} \mathrm{Ca}^{2+}, 15 \mathrm{mM}$ HEPES buffer (pH 7.2-7.3), 0.125 $\mathrm{mg} / \mathrm{ml}$ elastase, $0.375 \mathrm{mg} / \mathrm{ml}$ soybean trypsin inhibitor, $1 \mathrm{mg} / \mathrm{ml}$ collagenase and $2 \mathrm{mg} / \mathrm{ml}$ bovine albumin, and incubated at $37^{\circ} \mathrm{C}$ for $90 \mathrm{~min}$. The arteries were then rinsed 2-3 times with enzymefree HBSS and single VSMCs were obtained by triturating with a syringe and needle. The cells were pelleted by centrifugation and suspended in $5 \mathrm{ml}$ of Dulbecco's modification of Eagle's medium (high glucose; Gibco, Grand Island, N.Y., USA) containing $25 \mathrm{~mm}$ HEPES and $10 \%$ fetal bovine serum (Atlanta Biologicals, Lawrenceville, Ga., USA). The cells were transferred into a $25-\mathrm{cm}^{2}$ flask and allowed to grow in a $\mathrm{CO}_{2}$ incubator. Medium was changed once every 2-3 days until confluent monolayers were formed. On confluency, the cells were trypsin dispersed and subcultured in $60-\mathrm{mm}$ dishes or glass coverslips for experimental studies. The identity of vascular smooth muscle cells was confirmed by staining with smooth muscle $\alpha$-actin by immunofluorescence as described in our previous publication [31]. Briefly, the cells grown in Lab-Tek chamber slides were incubated with FITClabeled anti-smooth muscle $\alpha$-actin antibody (Sigma, St. Louis, Mo., USA) diluted 1:200 in blocking solution for $1 \mathrm{~h}$, then washed 3 times in PBS to remove unbound antibody. After the final wash, all slides were mounted in 50\% glycerol-PBS containing $1 \mathrm{mg} / \mathrm{ml}$ DAPI (Sigma) to label nuclei. Fluorescence in cells was examined using Olympus fluorescence microscope. The cells were serum starved for $48 \mathrm{~h}$ to render them quiescent before experiments. Low-passage cells (passages 4-7) were used for the study.

\section{Measurement of Intracellular $\mathrm{Ca}^{2+}$ Concentration}

PE-induced changes in intracellular $\mathrm{Ca}^{2+}$ concentration $\left(\left[\mathrm{Ca}^{2+}\right]_{i}\right)$, in the absence and presence of Raf- 1 kinase inhibitor, were measured with the ratiometric $\mathrm{Ca}^{2+}$-sensitive dye Fura-2 AM (Molecular Probes, Eugene, Oreg., USA) using a dual excitation digital $\mathrm{Ca}^{2+}$ imaging system (MetaFluor; Universal Imaging,
Downingtown, Pa., USA) equipped with an intensified chargecoupled device. The imaging system was mounted on an inverted microscope (Nikon Inc., Melville, N.Y., USA) outfitted with a magnification of $\times 40$ oil immersion objective. Mesenteric VSMCs grown in glass coverslips were loaded with $3 \mu \mathrm{M}$ Fura-2 AM in PBS for 20-30 min at room temperature in the dark. Cells were washed 3 times with HBSS and then incubated in that medium for $30 \mathrm{~min}$ for dye esterification. Measurements of $\left[\mathrm{Ca}^{2+}\right]_{\mathrm{i}}$ before and during pharmacological manipulation were made once the Fura-2 fluorescence ratio was stabilized. PE was added to cells pretreated with either vehicle or GW5074 $(10 \mu \mathrm{M})$ for 30 min and then $\left[\mathrm{Ca}^{2+}\right]_{\mathrm{i}}$ changes were recorded. In some experiments, GW5074 was added at the plateau of PE-induced increase in $\left[\mathrm{Ca}^{2+}\right]_{\mathrm{i}}$. Cells were illuminated with a xenon arc lamp at 340 and $380 \mathrm{~nm}$ (Omega Optical, Brattleboro, Vt., USA), and emitted light was collected every $1 \mathrm{~s}$ from regions that encompassed 10-15 cells with a charge-coupled device at $510 \mathrm{~nm}$. The relative changes in $\left[\mathrm{Ca}^{2+}\right]_{\mathrm{i}}$ were expressed as the ratio of the $340-$ to $380-\mathrm{nm}$ wavelengths.

\section{Determination of Raf-1, MEK, ERK, MLC 20 and MYPT1} Phosphorylation

Protein phosphorylation studies were performed as described previously [31]. Briefly, VSMCs cultured on a $60-\mathrm{mm}$ dish were stimulated with different doses of PE $(0.1,0.3,1,3$ and $10 \mu \mathrm{M})$ for $5 \mathrm{~min}$ or a fixed dose $(10 \mu \mathrm{M})$ for various time periods $(0,0.5,1$, 2.5, 5 and $10 \mathrm{~min}$ ) in the absence and presence of GW5074. The reactions were terminated by adding $10 \%$ trichloroacetic acid, followed by scraping with a rubber policeman. The trichloroacetic acid-fixed cells were washed with acetone containing $5 \mathrm{~mm}$ dithiothreitol and solubilized in SDS sample buffer and electrophoresed on 10\% SDS-polyacrylamide gel and transferred onto nitrocellulose membrane. Membranes were blocked in a PBS solution containing $5 \%$ dry milk for $2 \mathrm{~h}$ before an overnight incubation in a Tris-buffered saline solution containing 5\% milk and probed with phospho-Raf-1 (1:1,000 dilution; Cell Signaling, Danvers, Mass., USA), phospho-MEK (1:2,000 dilution; Cell Signaling), phospho-ERK (1:1,000 dilution; Cell Signaling), phospho-MLC ${ }_{20}$ (1:4,000 dilution; Sigma), phospho-myosin phosphatase target, MYPT1 $^{\text {Thr696 }}$ antibody (1:2,000; Upstate, Lake Placid, N.Y., USA). Membranes were washed using Tris-buffered saline containing $1 \%$ milk and then incubated with horseradish peroxidase-conjugated secondary antibody (dilution 1:2,000; Cell Signaling) for $1 \mathrm{~h}$. Immunoreactive bands were visualized by enhanced chemiluminescence (Pierce Biotechnology, Rockford, Ill., USA). Developed films from enhanced chemiluminescence were scanned and analyzed using the Fluor Chem program; care was taken to avoid saturation of exposures for densitometry. The results were normalized with $\beta$-actin (Sigma). In some experiments, cells were also stimulated with phorbol 12,13-dibutyrate (PDBu; $10 \mu \mathrm{M})$ for $15 \mathrm{~min}$ in the presence and absence of GW5074 (10 $\mu \mathrm{M})$, U0126 (MEK/ERK inhibitor; $10 \mu \mathrm{M}$ ) or calphostin C (PKC inhibitor; 100 $\mathrm{nM})$. The levels of protein phosphorylation were determined as described above.

\section{Drugs and Chemicals}

Stock solution of PE (Sigma) was prepared in distilled water, 5-HT (Sigma) in $0.1 \mathrm{~N} \mathrm{HCl}$ and U46619 (Sigma) in methanol. Raf1 kinase inhibitors (GW5074, L 779450 and ZM 336372; Calbiochem, Gibbstown, N.J., USA), U0126 (Sigma), PDBu (Sigma) and 


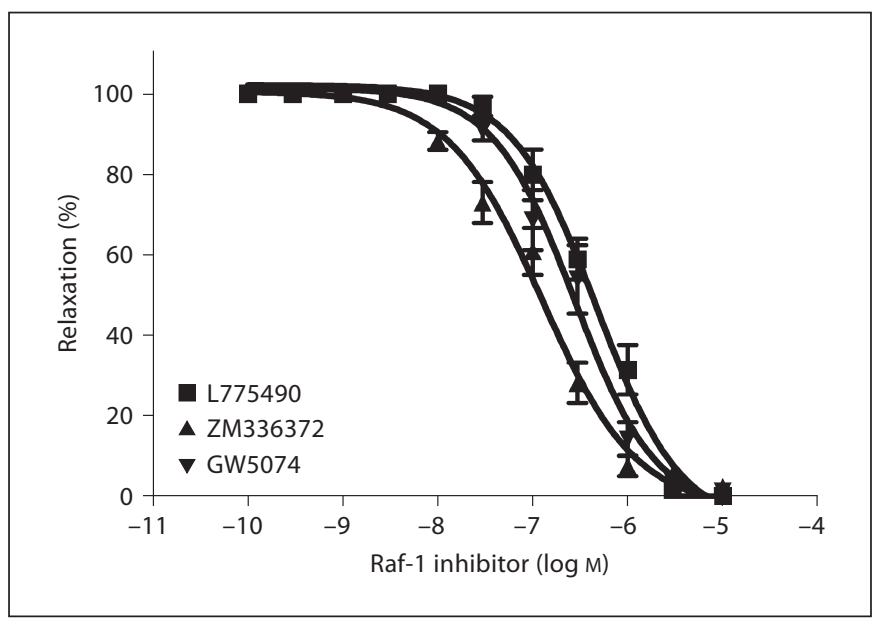

Fig. 1. Reversal of PE-induced contraction by Raf-1 kinase inhibitors in rat mesenteric arteries (semi-log plot). Submaximal PE contraction was elicited, increasing concentrations of Raf-1 kinase inhibitors, GW5074, L779450 and ZM33637, were added, and then the percentage of relaxation to PE contraction was measured. Data points represent mean \pm SEM of measurements in $10-12$ mesenteric arterial rings from 5-6 rats.

calphostin C (Sigma) were dissolved in DMSO. Angiotensin II and endothelin 1 (Calbiochem) were dissolved in 5\% acetic acid. The final concentration of vehicle in solution was $<0.1 \%$. All other chemicals were of reagent grade or better.

\section{Statistical Analysis}

The results are shown as mean \pm SEM and compared by analysis of variance followed by Bonferroni's correction for multiple comparisons. When comparisons were made between control and drug treatment in the same preparation, Student's paired $t$ test was used. $\mathrm{p}<0.05$ was considered statistically significant. $\mathrm{EC}_{50}$ concentrations were determined by regression analysis and expressed as negative log molar concentration $\left(\mathrm{pD}_{2}\right)$. Data analysis was done using GraphPad Prism version 4.00 for Windows (GraphPad Software, San Diego, Calif., USA).

\section{Results}

\section{Raf-1 Kinase Inhibitors Reverse PE-Induced}

\section{Contraction in Rat Mesenteric Arteries}

To examine whether activation of Raf-1 participates in the excitation-contraction coupling of rat mesenteric arteries during PE stimulation, the effects of three potent and selective inhibitors for Raf-1 activation, GW5074, L779450 and ZM336372 were investigated. As shown in figure 1, all three inhibitors completely reversed the contractile effect produced by $\mathrm{PE}$ (at $\mathrm{pEC}_{80}$ concentration).

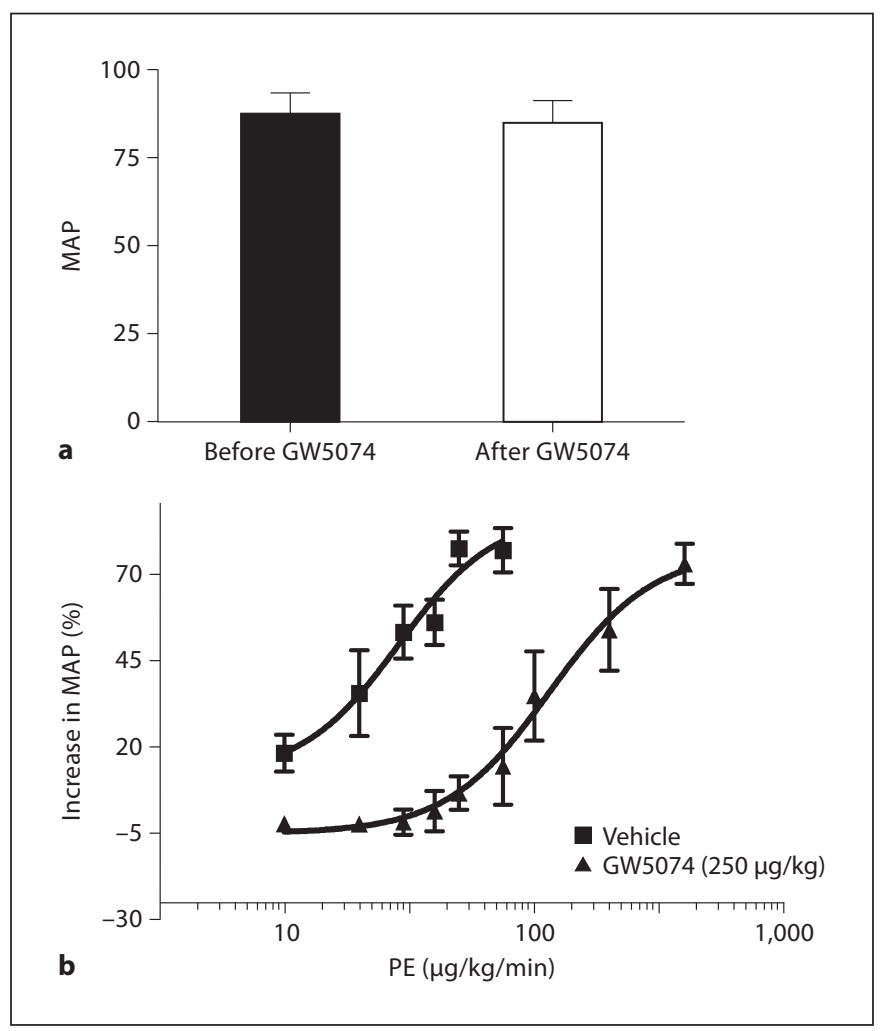

Fig. 2. a Basal MAP in rats in the absence and presence of GW5074 $(250 \mu \mathrm{g} / \mathrm{kg})$. b Effect of Raf-1 kinase inhibition on PE-induced increase in mean arterial pressure in rats. Dose-response curve for PE evoked increase in blood pressure in the absence and presence of GW5074 (semi-log plot). Rats were pretreated with GW5074 (250 $\mu \mathrm{g} / \mathrm{kg}$; i.v.) or vehicle for $15 \mathrm{~min}$ and then increasing concentration of PE was infused (10-300 $\mu \mathrm{g} / \mathrm{kg} / \mathrm{min})$. Each dose of PE was infused for a 3-min period and the MAP was determined as the mean value recorded within the last minute of infusion. Hypertensive responses were calculated as percent increase in MAP with respect to the baseline MAP. Values are expressed as mean \pm SEM of 5-6 animals.

The $\mathrm{IC}_{50}$ for GW5074, L779450 and ZM336372 are 0.40 $\pm 0.08,0.52 \pm 0.12$ and $0.17 \pm 0.03 \mu \mathrm{M}$, respectively $(\mathrm{n}=5-6)$. Since GW5074 is the common and extensively used Raf-1 inhibitor, we selected this for further studies.

\section{Inhibition of Raf-1 Kinase Inhibits PE-Induced \\ Increase in Blood Pressure in Rats}

GW5074 by itself did not have any effect on the basal MAP ( $88 \pm 5.4$ vs. $85 \pm 6.2 \mathrm{~mm} \mathrm{Hg}$; $=5-6$; fig. $2 \mathrm{a}$ ). To determine if Raf-1-dependent processes influence blood pressure, the effect of selective Raf-1 kinase inhibitor GW5074 on PE-induced increase in blood pressure was evaluated. In rats, incremental infusions of PE (10-100 

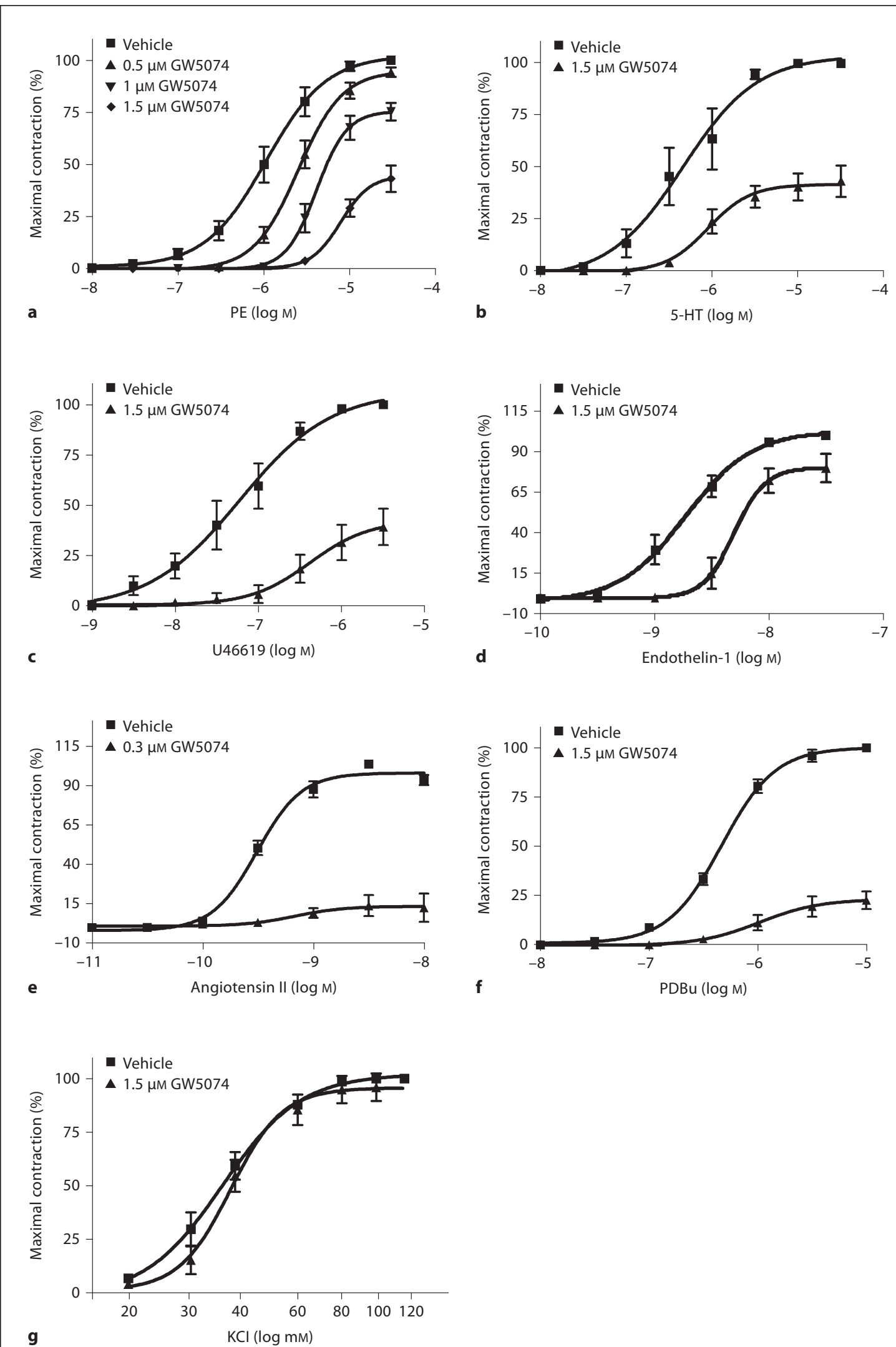
$\mu \mathrm{g} / \mathrm{kg} / \mathrm{min} ; \mathrm{n}=5$ ) caused significant and progressive increases in MAP $(103.6 \pm 1.7$ to $180.12 \pm 1.2 \mathrm{~mm} \mathrm{Hg})$ in a dose-dependent manner with an $\mathrm{EC}_{50}$ of $29 \pm 4.6 \mu \mathrm{g} /$ $\mathrm{kg} / \mathrm{min}$. After GW5074 $(250 \mu \mathrm{g} / \mathrm{kg})$, however, the MAP response to $\mathrm{PE}$ infusion $(10-300 \mu \mathrm{g} / \mathrm{kg} / \mathrm{min} ; \mathrm{n}=6)$ was significantly attenuated with shift in the dose-response curve to the right $\left(\mathrm{EC}_{50}: 115 \pm 12.3 \mu \mathrm{g} / \mathrm{kg} / \mathrm{min}\right)$. The percentage change from baseline (\%MAP) was significantly less at all doses of PE in animals pretreated with GW5074 (fig. 2b).

\section{Inhibition of Raf-1 Kinase Attenuates Agonist-Induced} Mesenteric Arterial Contraction

To further evaluate the role of Raf- 1 on vascular contraction, we assessed the effect of GW5074 on agonistinduced contraction in isolated rat mesenteric arteries. Inhibition of Raf-1 kinase with GW5074 showed no effect on basal tension in the mesenteric arteries of rat. GW5074 $(0.5,1$ and $1.5 \mu \mathrm{M} ; \mathrm{n}=6)$ produced a significant rightward shift in the concentration-response curve and attenuated the maximal force $\left(\mathrm{E}_{\max }\right)$ to $\mathrm{PE}$ in a dose-dependent manner (fig. 3a; table $1 ; n=6$ ). Removal of the endothelium did not change the inhibitory effects of GW5074 on PE-induced contractions (data not shown). GW5074-induced inhibition of PE contraction is reversible, with the contraction recovering to $85-100 \%$ of preinhibitory values after washout of GW5074. Similar results were obtained with GW5074 pretreatment in 5-HT, U46619, endothelin 1- and angiotensin II-induced contraction (fig. $3 \mathrm{~b}-\mathrm{e}$; table $1 ; \mathrm{n}=5-6$ ). Figure $3 \mathrm{f}$ depicts the effects of GW5074 on PKC-mediated contractions induced by $\mathrm{PDBu}$ in rat mesenteric artery. GW5074 (1.5 $\mu \mathrm{M})$ significantly inhibited the contractions induced by $\mathrm{PDBu}$ with suppression of maximal response (fig. 3f; table $1 ; \mathrm{n}=5$ ).

Fig. 3. Effect of Raf-1 kinase inhibition on the contraction induced by PE (a), 5-HT (b), U46619 (c), endothelin 1 (d), angiotensin II (e), $\mathrm{PDBu}(\mathbf{f})$ and $\mathrm{KCl}(\mathbf{g})$ in rat mesenteric arteries. Arterial rings were pretreated with indicated concentration of GW5074 or with the vehicle for $30 \mathrm{~min}$ and then subjected to the cumulative addition of agonists or KCl in Krebs solution. Data are expressed as percentages of maximal contraction, and each point represents mean \pm SE of 4-6 animals. Relative force is expressed as percentage of maximal force obtained by agonist in the absence of inhibitor.
Table 1. Effect of Raf-1 kinase inhibition on agonist-mediated contraction in mesenteric arteries of rats

\begin{tabular}{|c|c|c|}
\hline & $\mathrm{pD}_{2}$ & $\mathrm{E}_{\max }$ \\
\hline PE & $5.98 \pm 0.12$ & 100 \\
\hline $\mathrm{PE}+0.5 \mu \mathrm{M}$ GW5074 & $5.56 \pm 0.07^{*}$ & $94.10 \pm 2.25^{*}$ \\
\hline $\mathrm{PE}+1 \mu \mathrm{M}$ GW5074 & $5.18 \pm 0.12^{*}$ & $75.27 \pm 4.23^{*}$ \\
\hline $\mathrm{PE}+1.5 \mu \mathrm{M}$ GW5074 & - & $43.14 \pm 6.31^{*}$ \\
\hline $5-\mathrm{HT}$ & $6.32 \pm 0.22$ & 100 \\
\hline $5-\mathrm{HT}+1.5 \mu \mathrm{M}$ GW5074 & - & $43.18 \pm 7.59^{*}$ \\
\hline U46619 & $7.29 \pm 0.24$ & 100 \\
\hline $\mathrm{U} 46619+1.5 \mu \mathrm{M}$ GW5074 & - & $39.18 \pm 9.07^{*}$ \\
\hline Endothelin 1 & $8.71 \pm 0.09$ & 100 \\
\hline Endothelin $1+1.5 \mu \mathrm{M}$ GW5074 & $8.2 \pm 0.08^{*}$ & $79.53 \pm 8.4^{*}$ \\
\hline Angiotensin II & $9.49 \pm 0.5$ & 100 \\
\hline Angiotensin II + $0.3 \mu \mathrm{M}$ GW5074 & - & $12.51 \pm 8.91^{*}$ \\
\hline $\mathrm{KCl}$ & $4.46 \pm 0.08$ & 100 \\
\hline $\mathrm{KCl}+1.5 \mu \mathrm{M}$ GW5074 & $4.58 \pm 0.02$ & $95.95 \pm 6.38$ \\
\hline $\mathrm{PDBu}$ & $6.34 \pm 0.04$ & 100 \\
\hline $\mathrm{PDBu}+1.5 \mu \mathrm{M}$ GW5074 & - & $22.68 \pm 4.51^{*}$ \\
\hline
\end{tabular}

Values are expressed as mean \pm SEM of 5-6 rats in each group. $\mathrm{pD}_{2}$ is presented as $-\log [\mathrm{M}]$ and $\mathrm{E}_{\max }$ is presented as percent of maximal contraction in the absence of inhibitor. ${ }^{*} p<0.05$ compared to the respective agonist in the absence of inhibitor.

The effect of GW5074 on KCl-induced contractions of mesenteric arteries is shown in figure $3 \mathrm{~g}$. In contrast to its effect on agonist-mediated contractions, GW5074 (1.5 $\mu \mathrm{M})$ had no effect on KCl-induced contractions in the mesenteric arteries of rat (fig. $3 \mathrm{~g}$; table $1 ; \mathrm{n}=5$ ).

\section{GW5074 Inhibits PE-Induced Raf-1 Activation but}

Has No Effect on MEK/ERK Phosphorylation

To clarify the role of Raf- 1 on the PE-induced responses, we examined the effects of PE and GW5074 on Raf-1 activity measured in mesenteric VSMCs. Phosphorylation of Raf-1 using phosphospecifc anti-Raf-1 antibody was used as the index of PE-induced Raf- 1 activation. PE caused a dose-dependent increase in Raf-1 phosphorylation (fig. 4a, left panel; $\mathrm{n}=4$ ). Maximally effective concentration of PE $(10 \mu \mathrm{M})$ markedly increased the phosphorylation levels of Raf-1 (fig. $4 a$, right panel; $n=4$ ). Inhibition of Raf-1 activation with GW5074 (10 $\mu \mathrm{M})$ significantly reduced PE-induced phosphorylation of Raf-1 (fig. 4a, right panel; $n=4$ ). Since activated Raf-1 is classically expected to activate its downstream effectors MEK/ERK, we examined the effect of PE and GW5074 on the phosphorylation levels of MEK and ERK. PE induced increase in the phosphorylation levels of MEK and 
ERK (fig. 4b, c; $\mathrm{n}=4-5$ ). However, pretreatment with GW5074 did not cause a significant inhibition of MEK or ERK activation (fig. $4 b, c ; n=5$ ).

GW5074 Does Not Inhibit PE-Induced Increases in $\left[\mathrm{Ca}^{2+}\right]_{i}$

We examined whether inhibition of Raf- 1 activation is associated with reduction in PE-induced increases in
$\left[\mathrm{Ca}^{2+}\right]_{\mathrm{i}}$. In the mesenteric arterial smooth muscle cells loaded with Fura-2, an increase in $\left[\mathrm{Ca}^{2+}\right]_{i}$ resulted in an increase in $\mathrm{F}_{340}$ with associated decrease in $\mathrm{F}_{380}$. The ratio of F340/F380 is used as a measure of relative changes in $\left[\mathrm{Ca}^{2+}\right]_{\mathrm{i}}$. Addition of PE $(10 \mu \mathrm{M})$ induced a rapid increase in $\left[\mathrm{Ca}^{2+}\right]_{\mathrm{i}}$ as shown in figure $5 \mathrm{a}$. Pretreatment with GW5074 $(10 \mu \mathrm{M})$ for $30 \mathrm{~min}$ did not have an effect on basal $\left[\mathrm{Ca}^{2+}\right]_{\mathrm{i}}$ as well as on PE-induced increase in $\left[\mathrm{Ca}^{2+}\right]_{\mathrm{i}}$

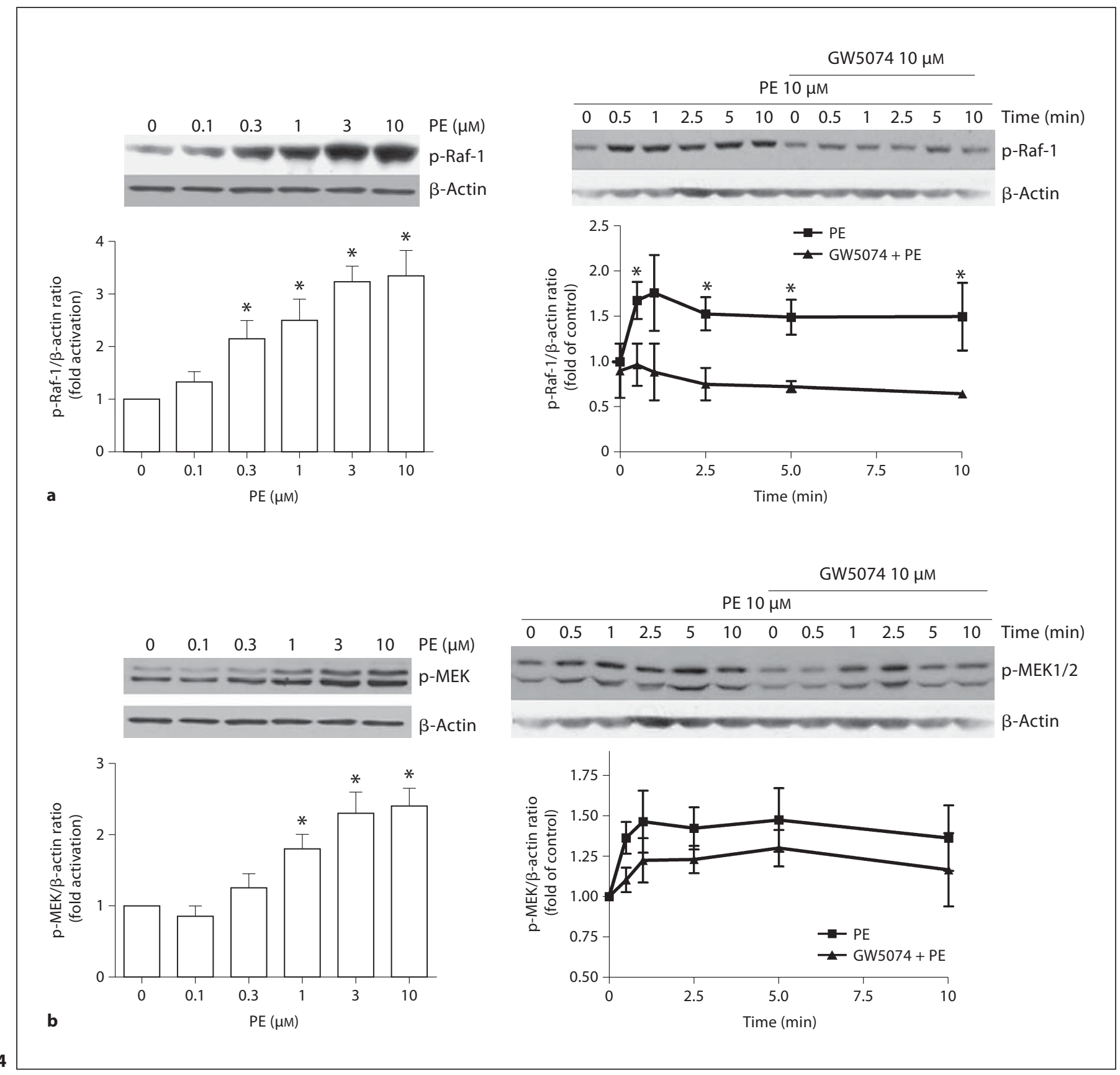


(fig. 5b). Although GW5074 prevented the typical PE-induced rapid increase in $\left[\mathrm{Ca}^{2+}\right]_{\mathrm{i}}$, it was without an effect on the maximal $\left[\mathrm{Ca}^{2+}\right]_{\mathrm{i}}$. Addition of GW5074 $(10 \mu \mathrm{M})$ at the plateau of PE-induced increase in $\left[\mathrm{Ca}^{2+}\right]_{i}$ caused a transient decrease in the Fura- $2 \mathrm{R}_{340 / 380}$, which then returned to pretreatment values (fig. $5 \mathrm{c}$ ). The changes in $\left[\mathrm{Ca}^{2+}\right]_{\mathrm{I}}$ (that is, average peak F340/F380 values) of PE in the absence and presence of GW5074 were not significantly different (fig. $5 \mathrm{~d} ; \mathrm{n}=3$ )

\section{Raf-1 Kinase Inhibition Attenuates PE-Induced} $M L C_{20}$ and MYPT Phosphorylation

Vascular contraction is known to be primarily associated with increased MLC phosphorylation, hence we evaluated whether the activation of Raf-1 pathway regulates MLC phosphorylation. PE caused a dose-dependent increase in $\mathrm{MLC}_{20}$ phosphorylation (fig. 6a, left panel; $\mathrm{n}=5$ ). Further, stimulation of VSMCs with $10 \mu \mathrm{M} \mathrm{PE}$ showed an increase in $\mathrm{MLC}_{20}$ phosphorylation with time (fig. $6 \mathrm{a}$, right panel; $\mathrm{n}=5$ ). Pretreatment with $10 \mu \mathrm{M}$
GW5074 for 30 min significantly decreased PE-induced $\mathrm{MLC}_{20}$ phosphorylation (fig. 6a, right panel; $\mathrm{n}=5$ ).

Raf-1 kinase is known to directly phosphorylate MYPT1 [25, 26], and the phosphorylated MYPT1 inhibits myosin phosphatase activity to cause a sustained MLC phosphorylation. Hence, we examined if Raf-1 kinase regulates MYPT1 phosphorylation. PE induced a dosedependent increase in MYPT1 phosphorylation in VSMCs (fig. 6b, left panel; $\mathrm{n}=3$ ). As shown in figure $6 \mathrm{~b}$, a PE-induced increase in MYPT1 phosphorylation was significantly inhibited by pretreatment with $10 \mu \mathrm{M}$ GW5074 (fig. 6b, right panel; $\mathrm{n}=3$ ).

\section{GW5074 Inhibits PKC-Induced Phosphorylation of}

Raf-1, MLC ${ }_{20}$ and MYPT1

Since the contraction induced by PKC activation was inhibited by GW5074, we examined the effects of PDBu on Raf- 1 activation. Activation of PKC with $\mathrm{PDBu}(3 \mu \mathrm{M})$ for $15 \mathrm{~min}$ resulted in increased phosphorylation of Raf-1 (fig. 7a; $\mathrm{n}=3$ ), $\mathrm{MLC}_{20}$ (fig. $7 \mathrm{~b} ; \mathrm{n}=3$ ) and MYPT1 (fig. 7c;

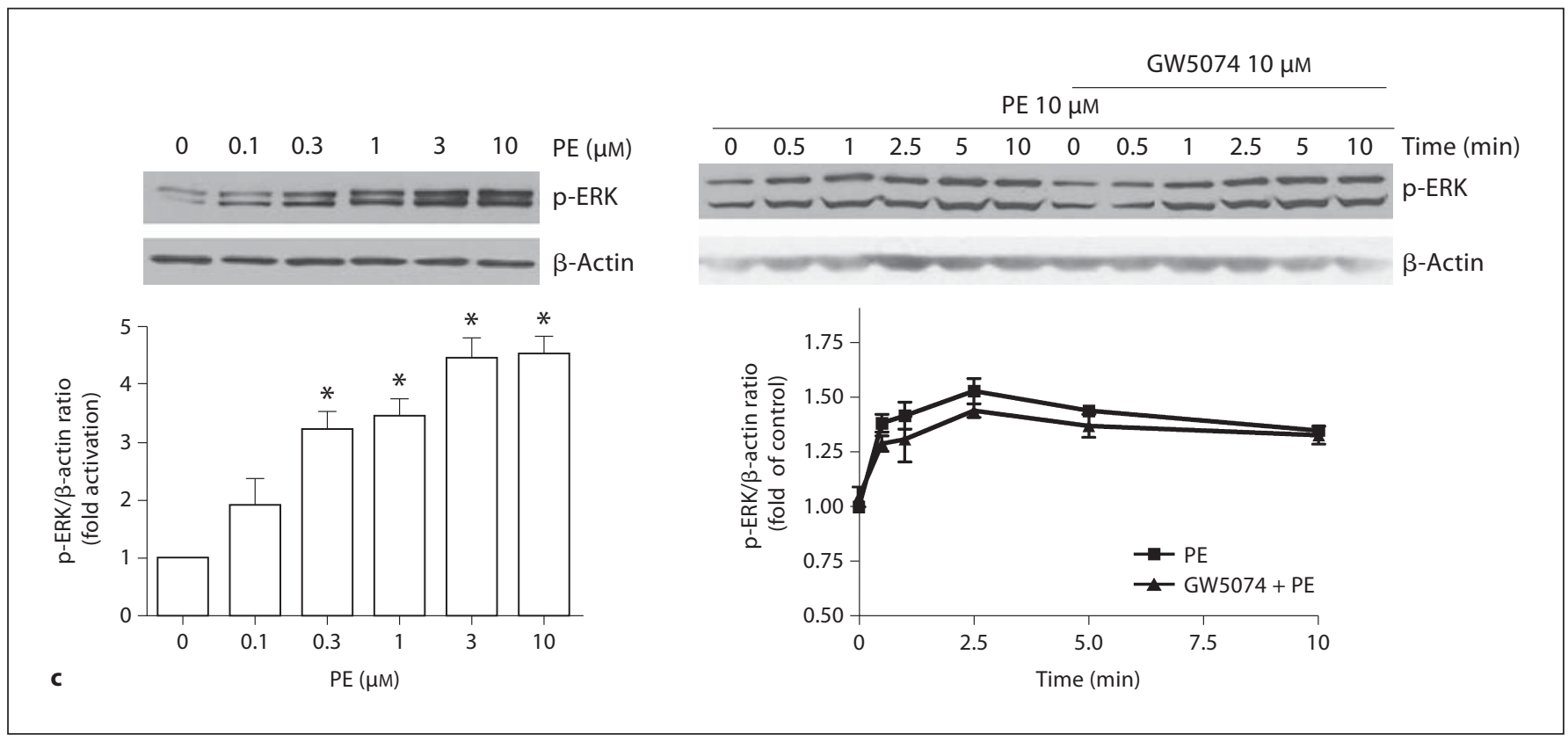

Fig. 4. Dose and time course of PE-stimulated phosphorylation of Raf-1 (a), MEK (b) and ERK (c). Left and right panels show concentration- and time-dependent effects of PE, respectively. Cultured VSMCs were treated with varying concentration of PE for $5 \mathrm{~min}$. For time course studies cells pretreated with GW5074 (10 $\mu \mathrm{M})$ or vehicle for $30 \mathrm{~min}$ before stimulated with PE $(10 \mu \mathrm{M})$ for indicated time periods. Treated cells were processed as described in Methods. The phosphorylation levels of Raf-1, MEK and ERK were determined by immunoblotting. Top panels show representative blots of respective phosphorylated proteins and $\beta$-actin; bottom panels are the summary of densitometric results. Results were normalized against $\beta$-actin and expressed as folds change relative to control. Data represent mean of 4-5 independent experiments. ${ }^{*} \mathrm{p}<0.05$ compared with their respective time point in the presence of GW5074. 

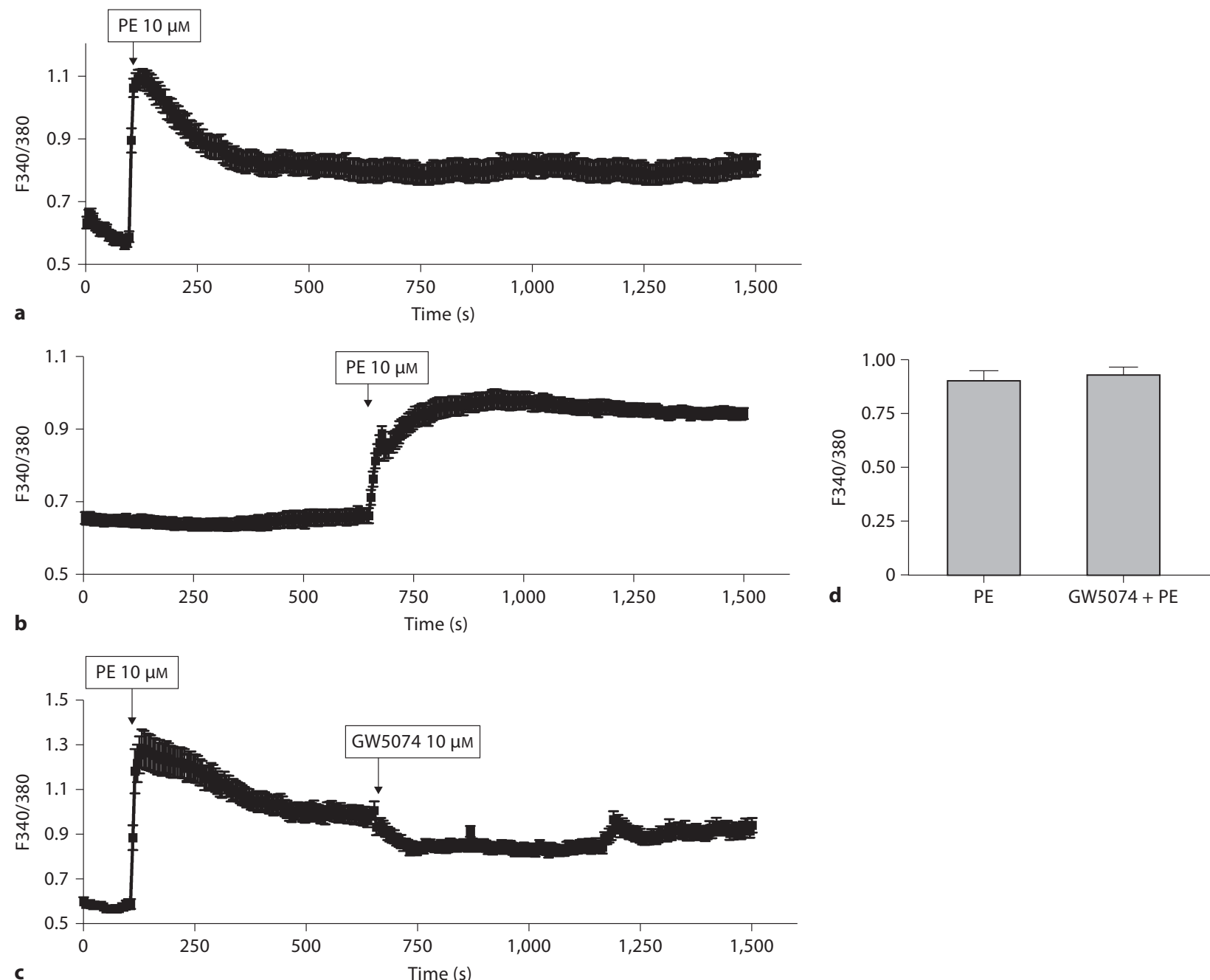

Fig. 5. Effect of Raf-1 kinase inhibition on PE-induced increases in $\left[\mathrm{Ca}^{2+}\right]_{i}$. Fura-2-loaded cultured VSMCs were pretreated with vehicle (a) or GW5074 (10 $\mu \mathrm{M})(\mathbf{b})$ for $30 \mathrm{~min}$ and then PE-induced increase in $\left[\mathrm{Ca}^{2+}\right]_{\mathrm{i}}$ was recorded in HBSS. c Effect of GW5074 when added at the plateau of PE-induced increase in $\left[\mathrm{Ca}^{2+}\right]_{\mathrm{i}}$. d Average peak F340/380 values for PE in absence and presence of GW5074. Data are expressed as F340/380 ratio after background correction, and each point represents mean \pm SE of 10-15 cells. Tracings are representatives and values are mean \pm SE from 3 separate experiments. $\mathrm{n}=3)$ in VSMCs and this was significantly inhibited by GW5074 $(10 \mu \mathrm{M})$. The PKC inhibitor, calphostin C (100 $\mathrm{nM}$ ) significantly inhibited the effects of $\mathrm{PDBu}$, but the MEK inhibitor, U0126, was without any effects on the $\mathrm{PDBu}$-induced phosphorylation of Raf-1, $\mathrm{MLC}_{20}$ and MYPT1 (fig. 7a-c; $\mathrm{n}=3$ ).

Also, PDBu induced significant increases in phosphorylation of MEK (fig. 6d) and ERK (fig. 6e). This was significantly inhibited by U0126 and calphostin C. Raf- 1 kinase inhibition with GW5074 inhibited only its immediate downstream effector, MEK, but not ERK phosphorylation (fig. 7d, e; n=3). GW5074, U0126 or calphostin $C$ by itself did not have any significant effects on the basal phosphorylation of these proteins compared to untreated controls. 


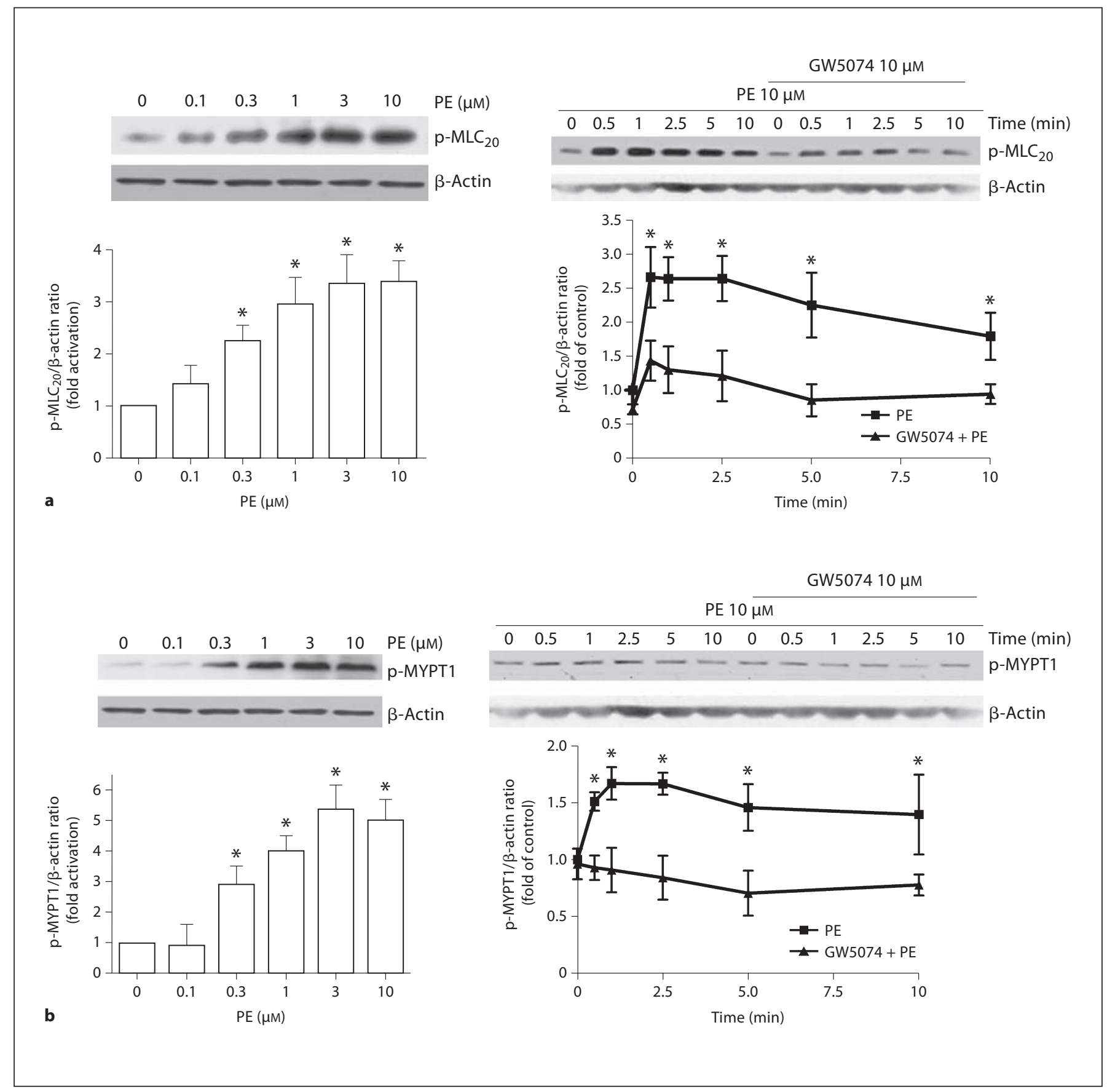

Fig. 6. Effects of Raf-1 kinase inhibition on PE-induced $\mathrm{MLC}_{20}$ (a) and MYPT1 (b) phosphorylation in rat VSMCs. Left and right panels show concentration- and time-dependent effects of PE, respectively. Cultured cells were pretreated with vehicle or GW5074 $(10 \mu \mathrm{M})$ for $30 \mathrm{~min}$ before stimulated with $10 \mu \mathrm{M}$ PE. Treated cells were processed as described in Methods. The phosphorylation levels of $\mathrm{MLC}_{20}$ or MYPT1 were determined by immunoblotting.
Top panels show representative blots of phospho- $\mathrm{MLC}_{20}$ or phospho-MYPT1 and $\beta$-actin, bottom panels are the summary of densitometric results. Results were normalized against $\beta$-actin and expressed as folds change relative to control. Data represent means of 3-5 independent experiments. ${ }^{*} \mathrm{p}<0.05$ compared with their respective time point in the presence of GW5074. 


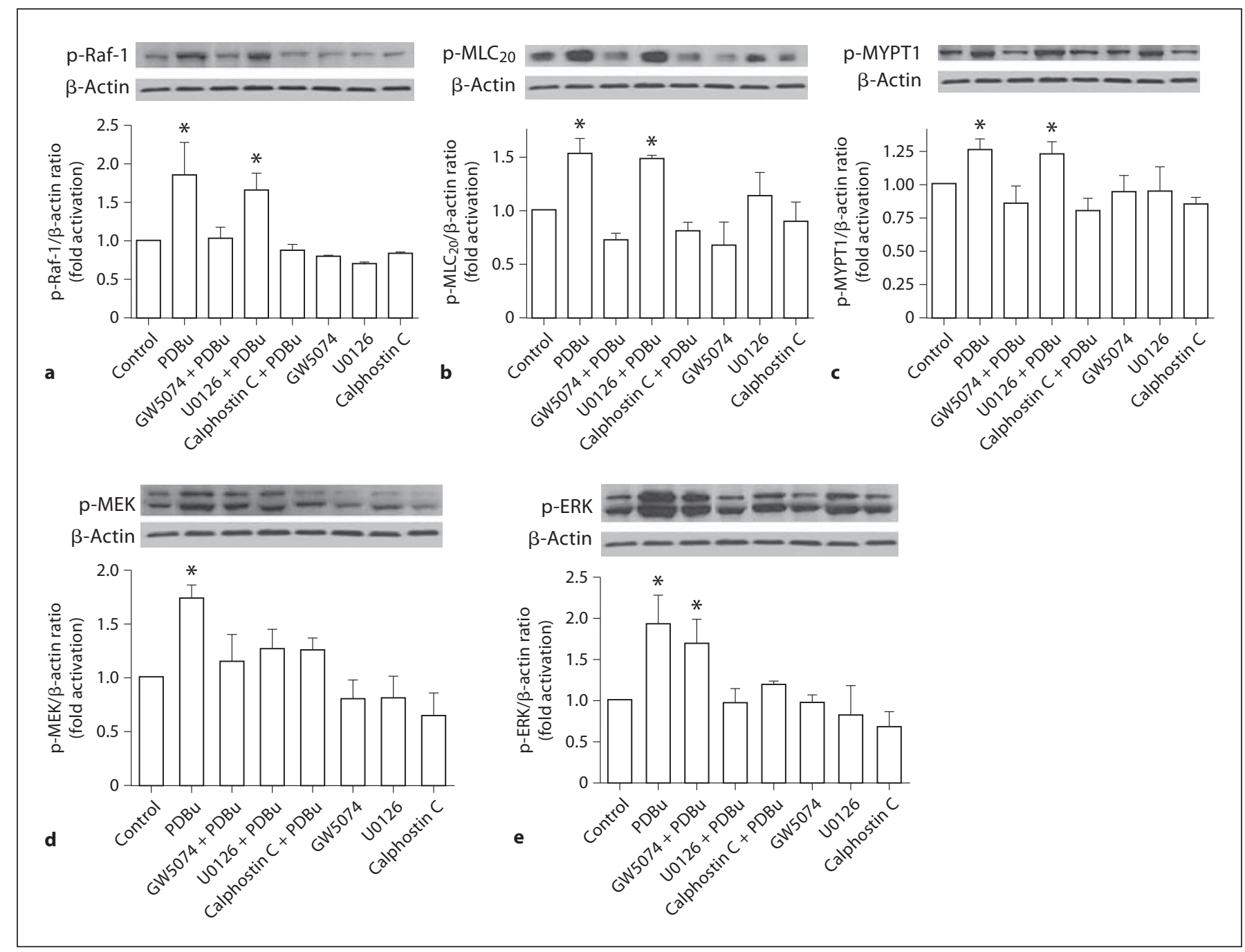

Fig. 7. Effects of Raf-1 kinase inhibition on PKC-induced Raf-1 (a), $\operatorname{MLC}_{20}(\mathbf{b}), \operatorname{MYPT1}(\mathbf{c}), \operatorname{MEK}(\mathbf{d})$ and ERK (e) phosphorylation in rat VSMCs. Cultured cells were pretreated with vehicle or GW5074 $(10 \mu \mathrm{M})$ or U0126 $(10 \mu \mathrm{M})$ or calphostin C $(100 \mathrm{nM})$ for $30 \mathrm{~min}$ before stimulated with $3 \mu \mathrm{M}$ PDBu for $15 \mathrm{~min}$. Treated cells were processed as described in Methods. The phosphorylation levels of these proteins were determined by immunoblotting. Top panels show representative blots of the respective phospho-protein and $\beta$-actin, bottom panels are the summary of densitometric results. Results were normalized against $\beta$-actin and expressed as folds change relative to untreated control. Data represent means of 3 independent experiments. ${ }^{*} \mathrm{p}<0.05$ compared to vehicle-treated control.

\section{Discussion}

The major findings of this study are: (1) Raf-1 kinase plays a role in agonist-mediated excitation-contraction coupling in intact vascular smooth muscle; (2) attenuation of agonist-mediated vascular contraction by inhibition of Raf- 1 kinase is not related with decrease in $\left[\mathrm{Ca}^{2+}\right]_{\mathrm{i}}$; (3) phosphorylation of MYPT1 associated with increased $\mathrm{MLC}_{20}$ phosphylation might contribute to PE/PKC-induced Raf-1 kinase-mediated vascular contraction; (4)
Raf-1-mediated MYPT1 and MLC $_{20}$ phosphorylation occurs without significant changes in MEK/ERK activation.

The aim of this present study was to determine whether the Raf-1 kinase is involved in vasoconstriction. The Raf-1/MEK/ERK signal transduction cascade has traditionally only been associated with growth-related processes such as activation of gene transcription [11]. However, recent studies have shown that this pathway can be involved in other, seemingly unrelated processes, such as 
vasoconstriction [6-8]. As contractile agonists have been shown to stimulate Raf-1 kinase in vascular smooth muscle cells grown in culture $[18,32,33]$, it is possible that a similar activation in blood vessels mediates vasoconstriction.

The selective $\alpha_{1}$-adreneoceptor agonist PE produced concentration-dependent contraction of the mesenteric artery. These contractions were inhibited by three selective Raf-1 kinase inhibitors, GW5074, L779450 and ZM336372. The degree of inhibition of PE response in the mesenteric artery by GW5074 (approximately 50-60\% inhibition by $1.5 \mu \mathrm{M}$ and complete inhibition at $10 \mu \mathrm{M}$ GW5074) suggests that the Raf-1 signal transduction cascade is an important signaling pathway involved in $\alpha_{1}$ adreneoceptor-mediated vasoconstriction. Similar inhibitory effects of GW5074 were also observed with vasoconstriction mediated by other contractile agonists such as 5-HT, U46619, endothelin 1 and angiotensin II. This suggests that Raf- 1 signal transduction cascade is involved in vasoconstriction mediated by a variety of contractile agonists unlike the ERK-mediated vasoconstriction which is shown to be agonist-specific [7]. Among the agonists examined in this study, angiotensin II-induced contractions were potently inhibited by GW5074. The reason for this is not known, but may suggest that Raf-1-mediated pathway may be an important pathway for angiotensin II-mediated contraction in vascular smooth muscle cells as recently reported [18]. The vasorelaxation effect of GW5074 was further confirmed by in vivo studies that show that the increase in blood pressure induced by PE could be significantly ameliorated by Raf1 kinase inhibition. Although adrenergic and other vasoactive systems contribute to the basal tone, this study shows that Raf-1 kinase inhibition does not alter basal tone as evident in both in vivo (mean arterial pressure) and ex vivo (vascular reactivity) studies; hence, it is possible that these systems do not activate Raf- 1 kinase at concentrations available at basal level.

Recent reports of attenuation of hypoxia-induced pulmonary hypertension by inhibition of Raf- 1 activation [34] suggests that Raf-1 does play a role in the regulation of vascular tone. GW5074 at $10 \mu \mathrm{M}$ caused complete inhibition of vascular contraction, and hence we used this concentration for studies in cultured VSMCs. Further, VSMCs in culture tend to become more proliferative and contractile with upregulated and activated Raf-1, and previous studies have shown that GW5074 at this concentration is effective to inhibit Raf-1 activation in cells under culture [35-37].

Raf-1 in Mesenteric Vascular Contraction
Further evidence for the involvement of Raf-1 in the $\alpha_{1}$-adrenoceptor-mediated vasoconstriction comes from immunoblotting experiments. It was shown that the degree of phosphorylation of Raf-1 in mesenteric VSMCs is increased after treatment with PE. Furthermore, phosphorylation of Raf- 1 was inhibited in cells pre-incubated with GW5074, demonstrating that these compounds do prevent activation of Raf- 1 . There is convincing evidence that stimulation of several $G$ protein-coupled receptors resulted in activation of Raf- 1 in cultured cells. For example, angiotensin II receptor activation, time- and concentration-dependently stimulated Raf-1 kinases in adrenal glomerulosa cells $[38,39]$. In primary cardiomyocytes, $\alpha_{1}$-adrenoceptor-activated Raf- 1 is reported to be involved in cardiac hypertrophy [12]. Also, in rat vascular smooth muscle cells, endothelin 1- and angiotensin IIactivated Raf-1 are shown to be involved in cell proliferation [18]. To our knowledge this is the first study to demonstrate a direct role for Raf-1 kinase in smooth muscle contraction.

It has been established that agonists activate Gq protein in several cell types including vascular smooth muscle cells, resulting in the PLC activation and the generation of diacylglycerol and $\mathrm{IP}_{3}$, leading to the activation of $\mathrm{PKC}$ and the release of $\mathrm{Ca}^{2+}$ from internal stores [40, 41]. Decrease in $\left[\mathrm{Ca}^{2+}\right]_{\mathrm{i}}$ is an important mechanism that promotes attenuation of vascular contraction. Therefore, we examined whether decreases in $\left[\mathrm{Ca}^{2+}\right]_{\mathrm{i}}$ were involved in GW5074-mediated inhibition of agonist-induced vascular contraction. The observation that Raf-1 kinase inhibition does not produce significant reduction in PE-induced increase in $\left[\mathrm{Ca}^{2+}\right]_{\mathrm{i}}$ suggests that modulation of $\left[\mathrm{Ca}^{2+}\right]_{\mathrm{i}}$ might not play a role in GW5074-mediated attenuation of vascular contraction. Although addition of GW5074 at the plateau of PE-induced increase $\left[\mathrm{Ca}^{2+}\right]_{i}$ caused a transient decrease in $\left[\mathrm{Ca}^{2+}\right]_{\mathrm{i}}$, this alteration was very little to effect a vasodilation. The reason why pretreatment of GW5074 attenuated the initial PE-induced peak increases $\left[\mathrm{Ca}^{2+}\right]_{\mathrm{i}}$ is not known at this time. However, the lack of involvement of changes in $\left[\mathrm{Ca}^{2+}\right]_{i}$ is further supported by the functional studies that show that GW5074 does not prevent $\mathrm{KCl}$-induced contraction in mesenteric arteries.

The absence of role for changes in $\left[\mathrm{Ca}^{2+}\right]_{\mathrm{i}}$ in PE-induced Raf-1 kinase-mediated contraction lead us to investigate the role of PKC. PKC is a predominant component in the kinase cascade initiated by the activation of $\mathrm{G}$ protein-coupled receptors. PKC has been shown to activate Raf-1 in many cell types examined $[42,43]$, and we obtained similar results in VSMCs. PDBu caused activa-

J Vasc Res 2010;47:384-398 
tion of Raf-1 similar to that caused by PE. The PKC inhibitor, calphostin $\mathrm{C}$, inhibited the responses to $\mathrm{PDBu}$ as expected. The implication that Raf- 1 is involved in PKCinduced vascular contraction is further supported by the observation that the contraction induced by PDBu in intact mesenteric arteries was inhibited by GW5074. Furthermore, the ability of GW5074 to inhibit contraction stimulated by U46619 (which primarily activates PKCmediated contraction in small mesenteric arteries [44]) further confirms that Raf-1 activation is involved in PKC-mediated contraction. This observation suggests that PKC may be the downstream mediator of agonistinduced Raf-1 activation; however, inhibition of PKC with calphostin $\mathrm{C}$ does not completely inhibit PE-induced Raf-1 phosphorylation (data not shown) meaning that Raf- 1 can be activated by both PKC-dependent and PKC-independent mechanisms similar to the observations reported in mouse mesenteric arteries [18] and bovine luteal cells [45].

Vascular smooth muscle contraction has been shown to be associated with agonist-induced phosphorylation of $\mathrm{MLC}_{20}$, the inhibition of which is associated with vasodilation. $\mathrm{PE} / \mathrm{PKC}$-induced $\mathrm{MLC}_{20}$ phosphorylation was inhibited by GW5074, suggesting that Raf-1 kinase inhibition may effect vasodilation by dephosphorylating the MLC. Phosphorylation of MLC is regulated by myosin light chain phosphatase. Increased phosphorylation of MYPT1, a subunit of myosin light chain phosphatase, decreases MLC phosphatase activity results in increased $\mathrm{MLC}_{20}$ phosphorylation and sustained vascular contraction. The observation that PE/PKC-induced MYPT1 phosphorylation was inhibited by GW5074 indicates that Raf-1 may mediate the phosphorylation of MYPT1 to cause increased $\mathrm{MLC}_{20}$ phosphorylation [27]. Indeed, studies have shown that following the activation of Raf-1, it associates with and phosphorylates MYPT1 in MDAMB 231 human breast cancer cells, implicating that myosin phosphatase can be a directly regulated by Raf-1 [26]. However, further studies are needed to clarify if similar mechanisms are operational in mesenteric VSMCs. This effect of Raf-1 to change in the phosphorylation state of $\mathrm{MLC}_{20}$ or MYPT1 without changes in intracellular calcium concentrations suggests that it may promote increase in 'calcium sensitivity', a well-known phenomenon that mediates vascular contraction [27]. Although rho kinase and CPI-17 phosphorylation are well-known players in mediating vascular contraction by increasing the sensitivity to calcium, any signaling interaction between these and Raf- 1 is not known at this time.
Activation of Raf-1 is usually followed by activation of the downstream kinase MEK, which in turn phosphorylates ERK. This is a classical proliferative pathway observed in many cell types. We found that PE/PKC induces Raf-1, MEK and ERK phosphorylation as expected, but inhibition of Raf-1 activation with pretreatment with GW5074 inhibits only Raf-1 phosphorylation and does not completely inhibit MEK and ERK activation. This suggests that (1) GW5074 regulates vascular contraction without the involvement of MEK/ERK similarly to previous reports in neuronal cells [46] and (2) agonist/PKC may have alternate or complementary MEK/ERK activation pathways as previously reported in vascular smooth muscle cells $[9,47]$, airway smooth muscle cells [48] and macrophages [49].

Although Raf-1 activation is typically shown to be associated with hypertrophy and/or hyperplasia, this study indicates that this kinase also regulates vascular contraction. Consequently, activation of Raf-1 may influence both vascular reactivity and remodeling, which are important processes in the development of hypertension. Hence, a better understanding of the role of Raf- 1 in these pathways may provide a new target to combat hypertension. Although evidence exists for Raf-1-regulating mitogenic responses and contractile function in blood vessels, these effects may be dependent on cell type. For example, activation of Raf-1 in smooth muscle cells within the medial layer may regulate contraction, whereas activation of Raf-1 in fibroblasts within the adventitial layer may be involved in vascular remodeling. It may also be possible that Raf-1 may interact with other regulatory contractile proteins. However, the exact cellular pathways by which Raf-1 influence agonist-mediated signaling in VSMCs await further clarification.

It is important to emphasize cautionary remark as the interpretations of this study concerning the functional role of Raf-1 kinase in vascular contraction are merely pharmacological. Although GW5074 is considered to be highly selective to Raf-1 kinase over other Raf isoforms like A-Raf and B-Raf and other kinases at the concentrations used in this study [46], further studies using genetic knockout mice/rat that lack Raf-1 kinase in the vascular smooth muscle are necessary to confirm the role of Raf-1 kinase in vascular contraction.

In summary, Raf- 1 kinase plays an important role in the regulation of vascular smooth muscle contractility. PE induces activation of Raf-1 kinase resulting in phosphorylation of MYPT1, inhibition of myosin phosphatase activity and maintenance of $\mathrm{MLC}_{20}$ phosphorylation. 


\section{References}

$\checkmark 1$ Berridge MJ: Inositol trisphosphate and calcium signalling. Nature 1993;361:315-325.

-2 Nishizuka Y: Turnover of inositol phospholipids and signal transduction. Science 1984; 225:1365-1370.

- 3 Tong XK, Hamel E: Transforming growth factor- $\beta 1$ impairs endothelin-1-mediated contraction of brain vessels by inducing mitogen-activated protein (MAP) kinase phosphatase-1 and inhibiting p38 MAP kinase. Mol Pharmacol 2007;72:1476-1483.

-4 Komers R, Schutzer W, Xue H, Oyama TT, Lindsley JN, Anderson S: Effects of p38 mitogen-activated protein kinase inhibition on blood pressure, renal hemodynamics, and renal vascular reactivity in normal and diabetic rats. Transl Res 2007;150:343-349.

5 Ihara E, Moffat L, Ostrander J, Walsh MP, MacDonald JA: Characterization of protein kinase pathways responsible for $\mathrm{Ca}^{2+}$ sensitization in rat ileal longitudinal smooth muscle. Am J Physiol Gastrointest Liver Physiol 2007;293:G699-G710.

-6 Tsai MH, Jiang MJ: Extracellular signal-regulated kinase1/2 in contraction of vascular smooth muscle. Life Sci 2005;76:877-888

$\checkmark 7$ Xiao D, Zhang L: ERK MAP kinases regulate smooth muscle contraction in ovine uterine artery: effect of pregnancy. Am J Physiol Heart Circ Physiol 2002;282:H292-H300.

-8 Luo G, Jamali R, Cao YX, Edvinsson L, Xu CB: Vascular endothelin ET(B) receptor-mediated contraction requires phosphorylation of ERK1/2 proteins. Eur J Pharmacol 2006; 538:124-131.

\9 Ginnan R, Guikema BJ, Singer HA, Jourd'heuil D: PKC- $\delta$ mediates activation of ERK1/2 and induction of iNOS by IL- $1 \beta$ in vascular smooth muscle cells. Am J Physiol Cell Physiol 2006;290:C1583-C1591.

10 Ginnan R, Singer HA: PKC- $\delta$-dependent pathways contribute to PDGF-stimulated ERK1/2 activation in vascular smooth muscle. Am J Physiol Cell Physiol 2005;288: C1193-C1201.

11 Kolch W: Meaningful relationships: the regulation of the Ras/Raf/MEK/ERK pathway by protein interactions. Biochem J 2000;351: 289-305.

- 12 Yamazaki T, Komuro I, Zou Y, Kudoh S, Shiojima I, Hiroi Y, Mizuno T, Aikawa R, Takano H, Yazaki Y: Norepinephrine induces the raf-1 kinase/mitogen-activated protein kinase cascade through both $\alpha 1$ - and $\beta$-adrenoceptors. Circulation 1997;95:12601268.

13 Kim N, Kim H, Youm JB, Park WS, Warda M, Ko JH, Han J: Site specific differential activation of ras/raf/ERK signaling in rabbit isoproterenol-induced left ventricular hypertrophy. Biochim Biophys Acta 2006;1763: 1067-1075.
14 Guerra B, Diaz M, Alonso R, Marin R: Plasma membrane oestrogen receptor mediates neuroprotection against $\beta$-amyloid toxicity through activation of Raf-1/MEK/ERK cascade in septal-derived cholinergic SN56 cells. J Neurochem 2004;91:99-109.

15 Harrisingh MC, Perez-Nadales E, Parkinson DB, Malcolm DS, Mudge AW, Lloyd AC: The Ras/Raf/ERK signalling pathway drives Schwann cell dedifferentiation. EMBO J 2004;23:3061-3071.

16 DeChant AK, Dee K, Weyman CM: Raf-induced effects on the differentiation and apoptosis of skeletal myoblasts are determined by the level of Raf signaling: abrogation of apoptosis by Raf is downstream of caspase 3 activation. Oncogene 2002;21: 5268-5279.

17 Samuel DS, Ewton DZ, Coolican SA, Petley TD, McWade FJ, Florini JR: Raf-1 activation stimulates proliferation and inhibits IGFstimulated differentiation in L6A1 myoblasts. Horm Metab Res 1999;31:55-64.

18 Yogi A, Callera GE, Montezano AC, Aranha $A B$, Tostes RC, Schiffrin EL, Touyz RM: Endothelin-1, but not Ang II, activates MAP kinases through c-Src independent Ras-Raf dependent pathways in vascular smooth muscle cells. Arterioscler Thromb Vasc Biol 2007;27:1960-1967.

19 Hong HJ, Chan P, Liu JC, Juan SH, Huang MT, Lin JG, Cheng TH: Angiotensin II induces endothelin-1 gene expression via extracellular signal-regulated kinase pathway in rat aortic smooth muscle cells. Cardiovasc Res 2004;61:159-168.

20 Krepinsky JC, Li Y, Tang D, Liu L, Scholey J, Ingram AJ: Stretch-induced Raf-1 activation in mesangial cells requires actin cytoskeletal integrity. Cell Signal 2005;17:311-320.

21 Liao DF, Duff JL, Daum G, Pelech SL, Berk BC: Angiotensin II stimulates MAP kinase kinase kinase activity in vascular smooth muscle cells, Role of Raf. Circ Res 1996;79: 1007-1014.

22 Baccarini M: An old kinase on a new path: Raf and apoptosis. Cell Death Differ 2002;9: 783-785.

-23 Hindley A, Kolch W: Extracellular signal regulated kinase (ERK)/mitogen activated protein kinase (MAPK)-independent functions of Raf kinases. J Cell Sci 2002;115: 1575-1581.

24 Janosch P, Kieser A, Eulitz M, Lovric J, Sauer G, Reichert M, Gounari F, Buscher D, Baccarini M, Mischak H, Kolch W: The Raf-1 kinase associates with vimentin kinases and regulates the structure of vimentin filaments. FASEB J 2000;14:2008-2021.

25 Abraham D, Podar K, Pacher M, Kubicek M, Welzel N, Hemmings BA, Dilworth SM, Mischak H, Kolch W, Baccarini M: Raf-1-associated protein phosphatase $2 \mathrm{~A}$ as a positive regulator of kinase activation. J Biol Chem 2000;275:22300-22304.
26 Broustas CG, Grammatikakis N, Eto M, Dent P, Brautigan DL, Kasid U: Phosphorylation of the myosin-binding subunit of myosin phosphatase by Raf- 1 and inhibition of phosphatase activity. J Biol Chem 2002;277: 3053-3059.

27 Hirano K, Hirano M, Kanaide H: Regulation of myosin phosphorylation and myofilament $\mathrm{Ca}^{2+}$ sensitivity in vascular smooth muscle. J Smooth Muscle Res 2004;40:219-236.

-28 Alessi D, MacDougall LK, Sola MM, Ikebe $\mathrm{M}$, Cohen P: The control of protein phosphatase- 1 by targetting subunits. The major myosin phosphatase in avian smooth muscle is a novel form of protein phosphatase-1. Eur J Biochem 1992;210:1023-1035.

29 Hartshorne DJ: Myosin phosphatase: subunits and interactions. Acta Physiol Scand 1998; 164:483-493.

- 30 Jensen PE, Gong MC, Somlyo AV, Somlyo AP: Separate upstream and convergent downstream pathways of G-protein- and phorbol ester-mediated $\mathrm{Ca}^{2+}$ sensitization of myosin light chain phosphorylation in smooth muscle. Biochem J 1996;318:469475.

31 Ross GR, Yallampalli U, Yallampalli C: Cyclic AMP-independent CGRP8-37-sensitive receptors mediate adrenomedullin-induced decrease of $\mathrm{CaCl}_{2}$-contraction in pregnant rat mesenteric artery. J Vasc Res 2008;45:3344.

32 Schumacher C, Cioffi CL, Sharif H, Haston W, Monia BP, Wennogle L: Exposure of human vascular smooth muscle cells to Raf-1 antisense oligodeoxynucleotides: cellular responses and pharmacodynamic implications. Mol Pharmacol 1998;53:97-104.

-33 Abe JI, Che W, Yoshizumi M, Huang Q, Glassman M, Ohta S, Wu Y, Arlinghaus R, Berk BC: Bcr in vascular smooth muscle cells involvement of Ras and Raf-1 activation by Bcr. Ann NY Acad Sci 2001;947:341-343.

- 34 Moreno-Vinasco L, Gomberg-Maitland M, Maitland ML, Desai AA, Singleton PA, Sammani S, Sam L, Liu Y, Husain AN, Lang RM, Ratain MJ, Lussier YA, Garcia JG: Genomic assessment of a multi-kinase inhibitor, sorafenib, in a rodent model of pulmonary hypertension. Physiol Genomics 2008;33: 278-291.

- 35 Yue X, Varga EV, Stropova D, Vanderah TW, Yamamura HI, Roeske WR: Chronic morphine-mediated adenylyl cyclase superactivation is attenuated by the Raf- 1 inhibitor, GW5074. Eur J Pharmacol 2006;540:57-59.

- 36 Varga EV, Rubenzik M, Grife V, Sugiyama M, Stropova D, Roeske WR, Yamamura HI: Involvement of Raf-1 in chronic delta-opioid receptor agonist-mediated adenylyl cyclase superactivation. Eur J Pharmacol 2002;451: 101-102. 
-37 Yue X, Varga EV, Stropova D, Vanderah TW, Yamamura HI, Roeske WR: Chronic morphine-mediated adenylyl cyclase superactivation is attenuated by the Raf- 1 inhibitor, GW5074. Eur J Pharmacol 2006;540:57-59.

-38 Watanabe T, Pakala R, Katagiri T, Benedict CR: Serotonin potentiates angiotensin II-induced vascular smooth muscle cell proliferation. Atherosclerosis 2001;159:269-279.

-39 Smith RD, Baukal AJ, Dent P, Catt KJ: Raf-1 kinase activation by angiotensin II in adrenal glomerulosa cells: roles of $\mathrm{Gi}$, phosphatidylinositol 3-kinase, and $\mathrm{Ca}^{2+}$ influx. Endocrinology 1999;140:1385-1391.

$\checkmark 40$ Webb ML, Taylor DS, Molloy CJ: Effects of thrombin receptor activating peptide on phosphoinositide hydrolysis and protein $\mathrm{ki}$ nase $\mathrm{C}$ activation in cultured rat aortic smooth muscle cells: evidence for 'tetheredligand' activation of smooth muscle cell thrombin receptors. Biochem Pharmacol 1993;45:1577-1582.

-41 Baldassare JJ, Henderson PA, Fisher GJ: Plasma membrane associated phospholipase $\mathrm{C}$ from human platelets: synergistic stimulation of phosphatidylinositol 4,5-bisphosphate hydrolysis by thrombin and guanosine 5'-O-(3-thiotriphosphate). Biochemistry $1989 ; 28: 56-60$.
42 Marais R, Light Y, Mason C, Paterson H, Olson MF, Marshall CJ: Requirement of RasGTP-Raf complexes for activation of Raf-1 by protein kinase C. Science 1998;280:109_ 112 .

43 Iijima Y, Laser M, Shiraishi H, Willey CD, Sundaravadivel B, Xu L, McDermott PJ, Kuppuswamy D: c-Raf/MEK/ERK pathway controls protein kinase C-mediated p70S6K activation in adult cardiac muscle cells. J Biol Chem 2002;277:23065-23075.

44 Budzyn K, Paull M, Marley PD, Sobey CG: Segmental differences in the roles of rho-kinase and protein kinase $\mathrm{C}$ in mediating vasoconstriction. J Pharmacol Exp Ther 2006; 317:791-796.

45 Chen DB, Davis JS: Epidermal growth factor induces c-fos and c-jun mRNA via Raf-1/ MEK1/ERK-dependent and -independent pathways in bovine luteal cells. Mol Cell Endocrinol 2003;200:141-154.
46 Chin PC, Liu L, Morrison BE, Siddiq A, Ratan RR, Bottiglieri T, D'Mello SR: The cRaf inhibitor GW5074 provides neuroprotection in vitro and in an animal model of neurodegeneration through a MEK-ERK and Akt-independent mechanism. J Neurochem 2004;90:595-608.

47 Maioli E, Torricelli C, Fortino V: Functional interactions of protein kinase $\mathrm{A}$ and $\mathrm{C}$ in signalling networks: a recapitulation. Cell Mol Life Sci 2006;63:637-641.

48 Kartha S, Naureckas ET, Li J, Hershenson MB: Partial characterization of a novel mitogen-activated protein kinase/extracellular signal-regulated kinase activator in airway smooth-muscle cells. Am J Respir Cell Mol Biol 1999;20:1041-1048.

49 Monick MM, Carter AB, Flaherty DM, Peterson MW, Hunninghake GW: Protein kinase $\mathrm{C}$ zeta plays a central role in activation of the p42/44 mitogen-activated protein $\mathrm{ki}$ nase by endotoxin in alveolar macrophages. J Immunol 2000;165:4632-4639. 